\title{
High Proportion of Vitamin D Deficiency in Male Adolescents in Yogyakarta Indonesia
}

\author{
Adika Zhulhi Arjana ${ }^{1,}$ Ninda Devita ${ }^{2}$, Titis Nurmasitoh ${ }^{3}$, Ika Fidianingsih $^{4}$, \\ Miranti Dewi ${ }^{5}$, Umatul Khoiriyah ${ }^{6, *}$ \\ ${ }^{1}$ Clinical Pathology and Laboratory Medicine Department, Faculty of Medicine Public Health and Nursing, \\ Universitas Gadjah Mada, Yogyakarta, Indonesia \\ ${ }^{2}$ Faculty of Medicine, Universitas Islam Indonesia, Yogyakarta, Indonesia \\ 3 Department of PhysiologyFaculty of Medicine, Universitas Islam Indonesia, Yogyakarta, Indonesia \\ 4 Department of Histology Faculty of Medicine, Universitas Islam Indonesia, Yogyakarta, Indonesia \\ 5 Department of Physiology Faculty of Medicine, Universitas Islam Indonesia, Yogyakarta, Indonesia \\ 6 Department of Medical Education, Faculty of Medicine, Universitas Islam Indonesia, Yogyakarta, Indonesia \\ *Corresponding author. Email: umakhoiriyah@uii.ac.id
}

\begin{abstract}
Deficiency of vitamin D in the world is high. Vitamin D deficiency has numerous negative effects. The purpose of this study was to determine the proportion of vitamin D deficiency in male adolescents in Yogyakarta Indonesia. This research is a cross-sectional study. The height, weight, physical activity, lipid profile laboratory data and vitamin D levels of subjects were recorded in the study. Body mass index (BMI) is calculated as body weight divided by height. Moderate exercise in physical is determined as enough activity for 150 minutes in week for moderate exercise and 75 minutes in week for strenuous exercise. Dyslipidaemia is diagnosed as an abnormal lipid level of three criteria: LowDensity Lipoprotein (LDL) $\geq 140 \mathrm{mg} / \mathrm{dl}$, High-Density Lipoprotein (HDL) $<40 \mathrm{mg} / \mathrm{dl}$, and triglyceride $\geq 150 \mathrm{mg} / \mathrm{dl}$.

Vitamin deficiency was determined using the enzymes linked immunoassay method by measuring the activity of 25 hydroxy vitamin D using serum samples of subjects. A total of 60 male adolescents aged 19-25 years participated in the study. A total of 30 subjects (50\%) had obesity with an average BMI of $29.65 \mathrm{~kg} / \mathrm{m} 2$. A total of 38 subjects had increased dyslipidaemia, with the highest proportion having low HDL (15\%). A total of 39 subjects $(65 \%)$ had had sufficient physical activity. The proportion of vitamin D deficiency was experienced by 26 subjects $(43.3 \%)$ while the proportion of vitamin D insufficiency was experienced by 31 subjects $(51.7 \%)$. Statistical analysis showed there was no correlation between the occurrence of vitamin D deficiency and obesity, dyslipidaemia and physical activity $\left(\mathrm{X}^{2}=0.778\right.$, $\left.\mathrm{p}=0.6779 ; \mathrm{X}^{2}=1.8, \mathrm{p}=0.4065 ; \mathrm{X}^{2}=0.087, \mathrm{p}=0.575\right)$. Proportion of vitamin $\mathrm{D}$ deficiency and insufficiency was quite high among male adolescents but not related to physical activity. Interventions are needed to treat conditions of vitamin D deficiency and insufficiency.
\end{abstract}

Keywords: vitamin D deficiency, obesity, physical activity

\section{INTRODUCTION}

The obesity prevalence continues to increase. According to research from the World Health Organisation (WHO), the obesity prevalence in 2016 was 650 million people. About $13 \%$ of young adults (>18 years) are obese. This number is three times that of 1975 [1]. The number of obesity cases is increasing in developed countries and developing countries neither. The incidence of obesity has tripled since 1980 in countries in Asia Pacific, China, Australia and the Middle East [2]. The prevalence of obesity in Southeast Asia was $1.7 \%$ in 1980 and had increased to $6.2 \%$ in 2015 [3].

Young adults are prone to obesity. According to previous studies, obesity is increasing by age from the age of 20, reaches a peak at the age of 50-65 years, then begins to decline. Obesity is more common in men than women [3]. Data from Riset Kesehatan Dasar (Riskesdas) shows that the proportion of obesity in people aged $>18$ years is $21.8 \%$. This figure has increased from $10.5 \%$ in 2007 compared to $14.8 \%$ in 2013 [4].

Obesity is caused by abnormal fat accumulation. It is assessed by BMI, which is the quotient of kilograms of body weight by the meters square of height [1]. WHO defines obesity as BMI $\geq 30 \mathrm{~kg} / \mathrm{m}^{2}$ and severe obesity as BMI $\geq 40 \mathrm{~kg} / \mathrm{m}^{2}$ [5]. However, for countries in Asia Pacific, WHO uses a limit of $\geq 25 \mathrm{~kg} / \mathrm{m}^{2}$ for obesity [6].

Vitamin D plays an important role in maintaining the balance of bone tissue, especially calcium and phosphate levels. A 1,25-dihydroxyvitamin D is active form of vitamin $\mathrm{D}$, not only has a function in 
maintaining the skeletal system, but also has nonskeletal functions such as reducing type 1 collagen production, maintaining muscular function, stimulating secretions of insulin, and maintaining the immune system. Vitamin D deficiency is defined as a serum concentration below $50 \mathrm{nmol} / \mathrm{L}$ or $20 \mathrm{ng} / \mathrm{mL}$ and vitamin D insufficiency is $20-29 \mathrm{ng} / \mathrm{mL}$ [7]. Both deficiency and insufficiency associated with several diseases. Vitamin D deficiency can cause osteoporosis in children and osteoarthritis in adulthood. In adults, low vitamin D levels can increase the risk of hypertension, diabetes, cardiovascular disease, and some types of cancer. Obese people who have low levels of vitamin D are more at risk of suffering from other diseases related to obesity. Vitamin D deficiency will lead to more severe obesity since enzymes that play a role in lipogenesis depend on vitamin D receptors $[8,9]$.

A previous study showed that obesity in all age groups is at risk of developing vitamin D deficiency. Vitamin D deficiency in obesity is caused by several factors. The first factor is the dilution of vitamin $\mathrm{D}$ in fat tissue. People with obesity tend to rarely do outdoor activities, and exposure to sunlight reduces vitamin D synthesis. Lack of vitamin D intake can also lead to vitamin D deficiency. Another possible mechanism is impaired hepatic enzyme 25-hydroxylation in obesity, which interferes with the process of vitamin $\mathrm{D}$ synthesis [8-10].

Some studies showed that vitamin D has related to lipid profile $[11,12]$. As vitamin D was increases intestinal calcium absorption, it reduces intestinal fatty acid absorption then lowering cholesterol level. Vitamin $\mathrm{D}$ also reducing triglyceride and low-density lipoprotein level [13]. Previous studies showed that people with sufficient vitamin D supplementation tend to have higher high-density lipoprotein level [14]. However, there is no clear evidence of direct mechanism as many factors could influencing.

The aim of this study was to determine the proportion of vitamin D deficiency among male adolescents in Yogyakarta Indonesia and their correlation with obesity, lipid profile, and physical

\section{METHODS}

This research is a cross-sectional study. It is the third report of a study entitled 'The Effect of Obesity on Low Physical Activity'. This research was funded by the Directorate of Research and Community Service, Directorate General of Research and Development Strengthening, Ministry of Research, Technology and Higher Education, Indonesia.

The subjects of this study were male adolescents who were categorised according their BMI based on Asia Pacific criteria. BMI was calculated by dividing body weight by height squared $\left(\mathrm{kg} / \mathrm{m}^{2}\right)$. Underweight is defined as BMI $<18,5 \mathrm{~kg} / \mathrm{m}^{2}$. Male with BMI $18.5-$ $22.9 \mathrm{~kg} / \mathrm{m}^{2}$ is defined as normal BMI. Male who overweight have BMI $23.0-24.9 \mathrm{~kg} / \mathrm{m}^{2}$. BMI in rane $25.0-29.9 \mathrm{~kg} / \mathrm{m}^{2}$ is obese I and $\geq 30 \mathrm{~kg} / \mathrm{m}^{2}$ is obese II [6]. The inclusion criteria for this study were males aged 18-30 years.

Subject recruitment was carried out through open announcements on social media starting in June 2018. Data collection was carried out at the Universitas Islam Indonesia, Yogyakarta. This research was approved by the Ethics Committee of the Faculty of Medicine, Universitas Islam Indonesia and obtained ethical approval with document number 48 / Ka.Kom.Et / 70 / $\mathrm{KE} / \mathrm{V} / 2018$.

The subjects' height and weight were measured by the nurse. Subsequently, the subjects filled out a questionnaire for exercise history and motivation. Blood was then taken from subjects to measure vitamin D levels using the enzyme linked immunoassay method. Data analysis used the Medcalc version 19.6, and p < 0.05 was significant result

\section{RESULTS AND DISCUSSION}

A total of 60 male adolescents aged 19-25 years participated in this study. None of subjects were underweight, meanwhile only 20 subjects $(33,33 \%)$ with normal BMI. Most of the subjects were having BMI $>23 \mathrm{~kg} / \mathrm{m}^{2}$. The baseline characteristics of the subjects can be seen in Table I. The mean age of the subjects was 21.5 years. The mean BMI of the subjects was $25.06 \mathrm{~kg} / \mathrm{m}^{2}$. A total of $33.34 \%$ of subjects had a frequency of exercise of 1 time/week, followed by $26.67 \%$ of subjects with a frequency of exercise of 2 times/week, $20 \%$ with 1 time/month, $13.34 \%$ with 3 times/week, and only $3.34 \%$ who exercise with a low intensity <1 time/week and a high intensity >3 times/week. Most of the subjects $(53.34 \%)$ did exercise with a duration of $60-120$ minutes, and only $11.67 \%$ of subjects exercised with a long duration of more than 120 minutes.

Physical activity is catagorized to moderate exercise (150 minutes activity per week) and vigorous exercise (75 minutes per week). Based on the above definition, $65 \%$ of the subjects had had sufficient physical activity (Fig. 1). However, $35 \%$ of the subjects did not meet the criteria for sufficient physical activity.

WHO defines physical activity as body movement by skeletal muscles that requires energy [15]. People who not enough for physical activity will have higher risk factor for non-communicable diseases [16]. Data shows that $23 \%$ of the world's population is not active enough [17]. Previous research data shows that sociodemographic factors, psychological factors and health status affect the desire for physical activity. Individual and socio-demographic factors are the most supportive of obesity [18]. In this study, $50 \%$ of the subjects had obesity; however, $35 \%$ of the subjects had not done sufficient physical activity. These results indicate that 
most of the obese subjects had done sufficient physical activity.

Tabel 1. Baseline Characteristics

\begin{tabular}{|c|c|c|}
\hline Characteristics & $\begin{array}{l}\text { Median (min- } \\
\text { max) }\end{array}$ & $\mathbf{N}(\%)$ \\
\hline Age (years) & $21.50(19-25)$ & \\
\hline $\operatorname{BMl}\left(\mathrm{kg} / \mathrm{m}^{2}\right)$ & $\begin{array}{l}25.06(19.36- \\
39.18)\end{array}$ & \\
\hline Underweight & & 0 \\
\hline Normal & & $\begin{array}{l}20 \\
(33,3 \%)\end{array}$ \\
\hline Overweight & & $\begin{array}{l}11 \\
(18,3 \%)\end{array}$ \\
\hline Obese I & & $\begin{array}{l}20 \\
(33,3 \%\end{array}$ \\
\hline Obese II & & $9(15,0 \%)$ \\
\hline \multicolumn{3}{|l|}{$\begin{array}{ll}\text { Physical } & \text { Activity } \\
\text { Frequency } & \end{array}$} \\
\hline \begin{tabular}{l|l} 
& $<1 \mathrm{x} /$ month \\
\end{tabular} & & $2(3.34 \%)$ \\
\hline $1 \mathrm{x} / \mathrm{month}$ & & $\begin{array}{l}12 \\
(20.00 \%)\end{array}$ \\
\hline 1x/week & & $\begin{array}{l}20 \\
(33.34 \%)\end{array}$ \\
\hline 2x/week & & $\begin{array}{l}16 \\
(26.67 \%) \\
\end{array}$ \\
\hline $3 x /$ week & & $\begin{array}{l}8 \\
(13.34 \%)\end{array}$ \\
\hline \begin{tabular}{l|l} 
& $>3 x /$ week \\
\end{tabular} & & $2(3.34 \%)$ \\
\hline \multicolumn{3}{|l|}{$\begin{array}{ll}\text { Physical Activity } \\
\text { Duration }\end{array}$} \\
\hline \begin{tabular}{l|l} 
& $>120$ minutes
\end{tabular} & & $\begin{array}{l}7 \\
(11.67 \%)\end{array}$ \\
\hline $60-120$ minutes & & $\begin{array}{l}32 \\
(53.34 \%)\end{array}$ \\
\hline 30-60 minutes & & $\begin{array}{l}13 \\
(21.67 \%)\end{array}$ \\
\hline$<30$ minutes & & $\begin{array}{l}8 \\
(13.34 \%)\end{array}$ \\
\hline
\end{tabular}

Physical Activity

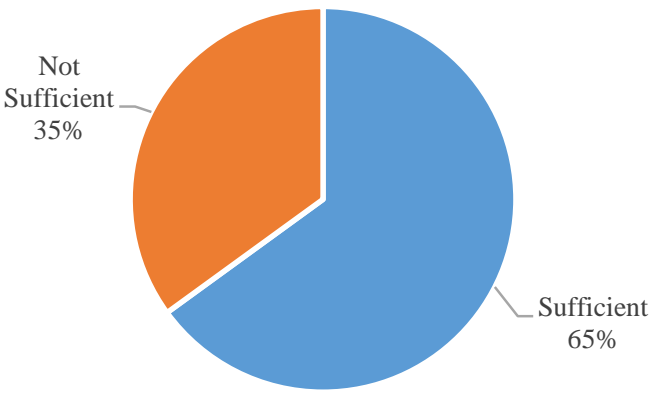

Figure 1. Physical Activity Sufficiency

From the examination of the lipid profile, the mean total cholesterol of the subjects was $180.73 \mathrm{mg} / \mathrm{dl}$, with $26.7 \%$ of the subjects having high total cholesterol. A total of $36.7 \%$ of subjects had high triglyceride levels, with an average triglyceride level of $116.5 \mathrm{mg} / \mathrm{dl}$. The mean high-density lipoprotein (HDL) was $42.58 \mathrm{mg} / \mathrm{dl}$, with $31.7 \%$ of subjects having low HDL. The mean lowdensity lipoprotein (LDL) was $121.75 \mathrm{mg} / \mathrm{dl}$, with $25 \%$ of subjects experiencing an increase in LDL levels (Table II). Fig. 2 shows that 38 subjects (63\%) had dyslipidaemia, with the highest proportion of subjects having low HDL (15\%).

Tabel 2. Characteristics of Lipid Profile

\begin{tabular}{|c|c|c|}
\hline Characteristics & $\begin{array}{c}\text { Mean } \pm \\
\text { SD/Median } \\
(\text { min-max) }\end{array}$ & $\mathbf{N}(\%)$ \\
\hline $\begin{array}{l}\text { Total Cholesterol } \\
\text { (mg/dl) }\end{array}$ & $\begin{array}{ll}180.73 & \pm \\
35.59 & \end{array}$ & \\
\hline High & & $16(26.7 \%)$ \\
\hline Normal & & $44(73.3 \%)$ \\
\hline $\begin{array}{l}\text { Triglyceride } \\
\text { (mg/dl) }\end{array}$ & $\begin{array}{l}116.50(37- \\
348)\end{array}$ & \\
\hline \begin{tabular}{l|l} 
& High \\
\end{tabular} & & $22(36.7 \%)$ \\
\hline \begin{tabular}{l|l|} 
& Normal \\
\end{tabular} & & $38(63.3 \%)$ \\
\hline $\mathrm{HDL}(\mathrm{mg} / \mathrm{dl})$ & $42.58 \pm 7.06$ & \\
\hline \begin{tabular}{l|l} 
& Low \\
\end{tabular} & & $19(31.7 \%)$ \\
\hline \begin{tabular}{l|l} 
Normal \\
\end{tabular} & & $41(68.3 \%)$ \\
\hline $\mathrm{LDL}(\mathrm{mg} / \mathrm{dl})$ & $\begin{array}{l}121.75 \\
34.17\end{array}$ & \\
\hline High & & $15(25.0 \%)$ \\
\hline Normal & & $45(75.0 \%)$ \\
\hline
\end{tabular}

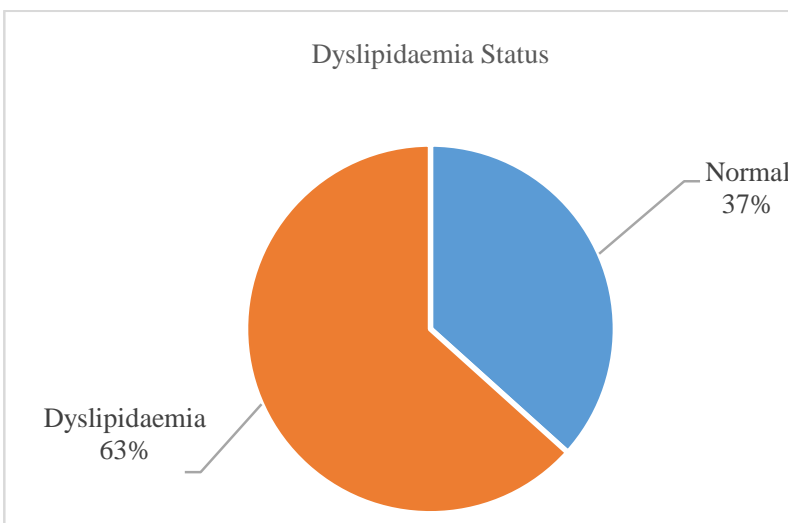

Figure 2. Dyslipidaemia status

Dyslipidaemia is defined as a group of metabolic disorders characterised by one or a combination of increased LDL cholesterol (LDL-C), increased total cholesterol, increased triglycerides, and low HDL cholesterol (HDL-C) [19]. Dyslipidaemia is a risk factor for metabolic syndrome. Research shows that subjects with dyslipidaemia have a high risk of cardiovascular events [20]. Furthermore, dyslipidaemia is closely related with the incidence of insulin resistance. This will result in worsening the metabolic process. The final effect of this combination is the failure of body metabolism [21]. The results of this study indicate that most of the subjects have dyslipidaemia. Although 65\% of the subjects had carried out adequate physical activity, the number with dyslipidaemia was still high. Low HDL is associated with insulin resistance when it is associated with Apo Al. Apo Al catabolism is 
increased in diabetes mellitus patients with low HDL through the mechanism of increasing hepatic lipase activity [20].

The incidence of vitamin D deficiency was experienced by 26 subjects $(43.3 \%)$ while the incidence of vitamin $\mathrm{D}$ insufficiency was experienced by 31 subjects (51.7\%) (Fig. 3). Table III shows the results of statistical analysis using the Chi Square test. The Chi Square analysis for the incidence of vitamin D status with obesity showed no relationship $\left(\mathrm{X}^{2}=0.778, \mathrm{p}=\right.$ 0.6779). The result of the same analysis for the incidence of vitamin $\mathrm{D}$ deficiency with dyslipidaemia was $\mathrm{X}^{2}=1.8, \mathrm{p}=0.4065$, which means there is no relationship between the two. The analysis for each component of the lipid profile also showed no relationship with vitamin D status. Furthermore, the analysis for physical activity variables showed no relationship between vitamin $\mathrm{D}$ status and physical activity $\left(\mathrm{X}^{2}=0.087, \mathrm{p}=0.575\right)$.

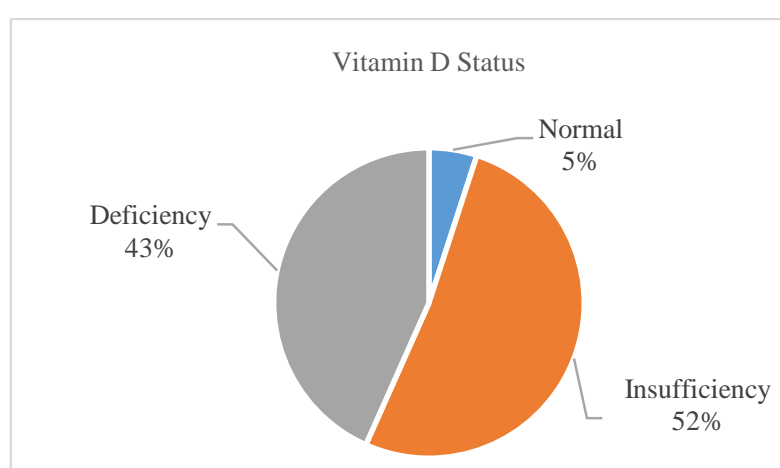

Figure 3. Vitamin D status

Tabel 3. Correlation of Vitamin D Status with BMI, Lipid Profile, and Physical Activity

\begin{tabular}{|c|c|c|}
\hline VARIABLES & $\mathbf{X}^{2}$ & $\mathbf{p}$ \\
\hline BMI & 1,501 & 0,9594 \\
\hline Lipid Profile & 1.8 & 0.4065 \\
\hline Total cholesterol & 0.557 & 0.7571 \\
\hline Triglyceride & 2.155 & 0.3405 \\
\hline $\mathrm{HDL}$ & 4.267 & 0.1184 \\
\hline \begin{tabular}{l|l} 
LDL \\
\end{tabular} & 0.173 & 0.9171 \\
\hline Physical Activity & 0.087 & 0.9575 \\
\hline
\end{tabular}

Vitamin D deficiency is experienced by over a billion people worldwide. Results of previous studies showed that vitamin D deficiency occurs in $34 \%$ of the population in tropical countries. Several factors cause this high proportion, including the perception of beauty from white skin and concerns about the adverse effects of sunlight [20]. Sun exposure is a major source of vitamin D. It takes 15-20 minutes of exposure to produce sufficient vitamin D. Data from a previous study in Indonesia showed that $82.8 \%$ of pregnant women were deficient in vitamin D [22]. The existence of this deficiency condition results in important metabolic disorders of the body. Several conditions are associated with vitamin D deficiency, including obesity, impaired immunity, and impaired growth in children $[8,9,23]$.

Vitamin D regulates calcium metabolism and inhibits the Parathyroid hormone (PTH). It was hypothetically that as sufficient vitamin D levels, the calcium concentration increase and lower PTH secretion. Both conditions resulted in lower cholesterol and increasing lipolytic activity $[12,13]$. However, there is no correlation of lipid profile and vitamin D status in this study. Many factors contributing to this result such as age, outdoor activity, and physical activity types.

Results of this study indicate high proportion of vitamin D deficiency. Age, outdoor activity, and perceptions related to beauty standards may be the causes. However, the proportion of vitamin D deficiency was high in this study

\section{CONCLUSIONS}

The proportion of vitamin D deficiency and insufficiency was quite high among male adolescents but not related to obesity, lipid profile, and physical activity. Interventions are needed to treat conditions of vitamin D deficiency and insufficiency.

\section{CONFLICT OF INTEREST}

The authors declare that the study was conducted in the absence of any commercial or financial relationships that could be construed as a potential conflict of interest.

\section{ACKNOWLEDGMENTS}

We express our gratitude to all subjects also Research and Community Service Directorate, General Directorate of Research Strengthening and Developing, Ministry of Research, Technology, and Higher Education, Indonesia for grant this research project with grant contract number 111/SP2H/LT/DRPM/2019

\section{REFERENCES}

[1] Levesque RJR. Obesity and Overweight. Encycl. Adolesc. 2011. p. 1913-5.

[2] Ellulu M, Abed Y, Rahmat A, Ranneh Y, Ali F. Epidemiology of obesity in developing countries: challenges and prevention. Glob Epidemic Obes. 2014;2:2.

[3] Chooi YC, Ding C, Magkos F. The epidemiology of obesity. Metabolism. Elsevier Inc.; 2019;92:6-10.

[4] Kementerian Kesehatan RI Badan Penelitian dan Pengembangan. Hasil Utama Riset Kesehatan Dasar. Kementrian Kesehat Republik Indones. 2018;1-100.

[5] World Health Organization (WHO). Obesity: 
Preventing and Managing the Global Endemic. WHO Tech. Rep. Ser. 2000.

[6] Nishida C, Barba C, Cavalli-Sforza T, Cutter J, Deurenberg P, Darnton-Hill I, et al. Appropriate body-mass index for Asian populations and its implications for policy and intervention strategies. Lancet. 2004;363:15763.

[7] Holick MF, Binkley NC, Bischoff-Ferrari HA, Gordon CM, Hanley DA, Heaney RP, et al. Evaluation, treatment, and prevention of vitamin D deficiency: An endocrine society clinical practice guideline. J Clin Endocrinol Metab. 2011;96:1911-30.

[8] Vranić L, Mikolašević I, Milić S. Vitamin D deficiency: Consequence or cause of obesity? Med. 2019;55.

[9] Pereira-Santos M, Costa PRF, Assis AMO, Santos CAST, Santos DB. Obesity and vitamin D deficiency: A systematic review and metaanalysis. Obes Rev. 2015;16:341-9.

[10] Vanlint S. Vitamin D and obesity. Nutrients. 2013;5:949-56.

[11] Kim MR, Jeong SJ. Relationship between vitamin $D$ level and lipid profile in non-obese children. Metabolites [Internet]. MDPI AG; 2019 [cited 2020 Nov 24];9.

[12] Rusconi RE, De Cosmi V, Gianluca G, Giavoli C, Agostoni C. Vitamin D insufficiency in obese children and relation with lipid profile. Int J Food Sci Nutr [Internet]. Informa UK Ltd; 2015;66:132-4.

[13] Wang Y, Si S, Liu J, Wang Z, Jia H, Feng K, et al. The associations of serum lipids with Vitamin D status. PLoS One. 2016;11:1-13.

[14] Zittermann A, Frisch S, Berthold HK, Götting C, Kuhn J, Kleesiek K, et al. Vitamin D supplementation enhances the beneficial effects of weight loss on cardiovascular disease risk markers. Am J Clin Nutr [Internet]. American Society for Nutrition; 2009 [cited 2020 Nov 24];89:1321-7.

[15] World Health Organization. Physical Activity and Adults [Internet]. WHO. World Health Organization; 2015 [cited 2020 Sep 6].

[16] Sheikholeslami S, Ghanbarian A, Azizi F. The impact of physical activity on noncommunicable diseases: Findings from 20 years of the Tehran lipid and glucose study [Internet]. Int. J. Endocrinol. Metab. Kowsar Medical Publishing Company; 2018 [cited 2020 Sep 6]. p. 84740.
[17] World Health Organization. Physical activity [Internet]. WHO. 2018 [cited 2020 Sep 2]. p. 227.

[18] Abadini D, Adriani M, Endah Wuryaningsih C. Determinants of Physical Activity Among Southeast Asian Adults: A Systematic Review. KnE Life Sci. 2019;4:294.

[19] Musunuru K. Atherogenic dyslipidemia: Cardiovascular risk and dietary intervention [Internet]. Lipids. Springer; 2010 [cited 2020 Sep 6]. p. 907-14.

[20] Ginsberg HN, Zhang YL, Hernandez-Ono A. Metabolic syndrome: focus on dyslipidemia. [Internet]. Obesity (Silver Spring). John Wiley $\&$ Sons, Ltd; 2006 [cited 2020 Sep 6]. p. 41S49S.

[21] Mancini GBJ, Hegele RA, Leiter LA. 2018 Clinical Practice Guidelines Dyslipidemia Diabetes Canada Clinical Practice Guidelines Expert Committee. 2018 [cited 2020 Sep 6];

[22] Aji AS, Erwinda E, Yusrawati Y, Malik SG, Lipoeto NI. Vitamin D deficiency status and its related risk factors during early pregnancy: A cross-sectional study of pregnant Minangkabau women, Indonesia. BMC Pregnancy Childbirth [Internet]. BioMed Central Ltd.; 2019 [cited 2020 Sep 6];19.

[23] Kennel KA, Drake MT, Hurley DL. Vitamin D deficiency in adults: When to test and how to treat [Internet]. Mayo Clin. Proc. Elsevier 